\section{Fertilizer Concentration Affects Growth and Foliar Elemental Concentration of Strobilanthes dyerianus}

\author{
Erin E. Gamrod ${ }^{1}$ and Holly L. Scoggins ${ }^{2}$ \\ Department of Horticulture, Virginia Tech, Blacksburg, VA 24061-0327
}

Additional index words. persian shield, nitrogen, bedding plant, tissue testing

\begin{abstract}
Grown as an annual in most of the United States, Strobilanthes dyerianus Mast. has become increasingly popular in summer landscapes partially due to its superior performance in hot and humid conditions. At present, there is no published research on the nutritional requirements of $S$. dyerianus. Our study examined growth and foliar elemental response to different levels of fertilizer. Rooted cuttings were transplanted and grown with $0,100,200,300$, and $400 \mathrm{mg} \cdot \mathrm{L}^{-1} \mathrm{~N}$ from $5 \mathrm{~N}-2.2 \mathrm{P}-12.4 \mathrm{~K}$ fertilizer as constant liquid feed. Plants were irrigated whenever the volumetric water content of the substrate was $<\mathbf{2 0} \%$ as determined with a Theta Probe moisture meter. Weekly $\mathrm{pH}$ and electrical conductivity (EC) were monitored using the pour through method. Eight weeks after initiation of treatment, dry weight and leaf area was measured. Recently mature leaf tissue was analyzed for total $\mathrm{N}, \mathrm{P}, \mathrm{K}, \mathrm{Ca}, \mathrm{Mg}, \mathrm{S}, \mathrm{Fe}, \mathrm{Mn}, \mathrm{B}, \mathrm{Cu}, \mathrm{Zn}$, and Mo. There were no significant differences in plant quality under the $100,200,300$, or $400 \mathrm{mg} \cdot \mathrm{L}^{-1} \mathrm{~N}$ treatments. The largest plants, based on leaf area and shoot dry weight, were produced with $200 \mathrm{mg} \cdot \mathrm{L}^{-1} \mathrm{~N}$. Compared to recommended EC levels for bedding plants, the treatments receiving 300 and $400 \mathrm{mg} \cdot \mathrm{L}^{-1} \mathrm{~N}$ had excessively high levels of substrate soluble salts though overall plant quality was not reduced. The increase in fertilizer concentration yielded a linear increase in tissue concentration of $\mathrm{N}, \mathrm{P}$, and $\mathrm{K}$ and a linear decrease in tissue concentration of $\mathrm{Ca}$ and $\mathrm{Mg}$.
\end{abstract}

Strobilanthes dyerianus (persian shield) has become a relatively popular bedding and landscape plant. A tropical perennial native to Burma in SoutheastAsia, S. dyerianus is grown for its foliage: large, sessile leaves marked with purple, green and silver. It is a member of the Athens Select program (Athens, Ga.), which is made up of plants demonstrating exceptional performance under hot and humid conditions (Armitage and Green, 2001).

To produce high quality, marketable plants, nutritional requirements must be established. Without proper nutrition, a plant cannot achieve optimal growth and may become more susceptible to stressors (Jones, 1998). Minimizing fertilizer runoff is an environmental concern for greenhouse and nursery operations. As such, growers are trying to produce plants using the least amount of fertilizer that produces the quality plants the consumer demands. There has been no published research regarding the nutritional requirements for $S$. dyerianus. The optimal concentration of fertilizer varies depending on the plant. Plants that require higher rates of nutrients, such as Euphorbia pulcherrima Willd. ex. Klotzsch (poinsettia) may be grown at a higher electrical conductivity or substrate soluble salt range (Whipker et al., 2001).

\footnotetext{
Received for publication 8 Dec. 2004. Accepted for publication 18 Oct. 2005. The research reported herein was funded in part by the Ohio Florist Foundation. The authors gratefully acknowledge the assistance of Velva Groover, Floriculture Research Technician. Mention of brands and products does not imply endorsement of this product by Virginia Tech.

${ }^{1}$ Graduate research assistant.

${ }^{2}$ Associate professor.
}

$1.5^{\circ} \mathrm{C}$ and the average night temperature was $21 \pm 2.2^{\circ} \mathrm{C}$. Day length ranged from $14 \mathrm{~h} 43$ min at the start of treatments to $13 \mathrm{~h} 16 \mathrm{~min}$ by the end of the experiment. No supplemental lights were used. Noon light levels over the course of the experiment averaged 1163 $\mu \mathrm{mol} \cdot \mathrm{m}^{-2} \cdot \mathrm{s}^{-1}$.

The experiment was arranged in a randomized complete block design with six replications. Within a block, plants were treated with five rates of fertilizer $\left(\mathrm{mg} \cdot \mathrm{L}^{-1}\right.$ based on nitrogen): $0 \mathrm{mg} \cdot \mathrm{L}^{-1}$ (tap water), 100,200 , $300,400 \mathrm{mg} \cdot \mathrm{L}^{-1} \mathrm{~N}$ from $15 \mathrm{~N}-2.2 \mathrm{P}-12.4 \mathrm{~K}$ (Miracle-Gro Excel 15-5-15, The Scotts Co., Marysville, Ohio) as constant liquid feed. This complete (includes micronutrients) fertilizer contains $78.3 \%(\mathrm{w} / \mathrm{w}) \mathrm{NO}_{3}{ }^{-} \mathrm{N}$ and $8.0 \%$ ammoniacal-N, with a slight potential basicity (141 $\mathrm{lb} \mathrm{CaCO}_{3}$ equivalent neutralized by one ton of fertilizer). Tap water $\mathrm{pH}$ ranged from 7.0 to 7.2 with alkalinity of $1 \mathrm{meq} \mathrm{L}^{-1} \mathrm{HCO}_{3}^{-}$. Plants were irrigated with $450 \mathrm{~mL}$ of solution to achieve a 0.20 to 0.30 leaching fraction when the volumetric substrate moisture content (VMC) was $20 \%$ or less, measured with a ThetaProbe (ThetaProbe soil moisture sensor; Delta-T Devices, Ltd, Cambridge, U.K.; TH20 meter; Dynamax, Inc., Houston, Texas). When the VMC of at least three of the six replications of a treatment dropped to $\leq 20 \%$, all pots in that treatment were watered. To measure substrate $\mathrm{pH}$ and $\mathrm{EC}$, the pour-through extraction method (Wright, 1986) was utilized once weekly (every 6 to $7 \mathrm{~d}$ ) for that particular treatment within one hour of an irrigation event. At the termination of the study, eight weeks after initiating treatments, plant quality was assessed, shoots were harvested, and leaf area determined. Plant quality was rated on a scale of 0 to 4 with 0 being dead, 1 having severe chlorosis and/or necrosis (or other deficiency symptom), 2 having moderate chlorosis and/or necrosis, 3 having mild chlorosis and/or necrosis and 4 with no chlorosis and/or necrosis.

Eight weeks after initiation of treatments, plants in all of the treatments except $0 \mathrm{mg} \cdot \mathrm{L}^{-1} \mathrm{~N}$ were deemed of marketable size, and leaf area measured using a portable area meter(LI-3000) with transparent belt conveyer accessory (LI3050A) (LI-COR, Inc., Lincoln, Nebr.). The aerial portions were washed then dried at 65.5 ${ }^{\circ} \mathrm{C}$ for $7 \mathrm{~d}$, and dry weight was recorded. Leaf tissue from recently mature leaves was then ground, combining two random plants from each treatment into one sample, for fifteen samples. Total nitrogen was determined using the Dumas method (Mills and Jones, 1996) with a C-N-S analyzer (model 2000; LECO Corp., St. Joseph, Mich.) which also was used to determine sulfur concentration. Phosphorous, potassium, calcium, magnesium, boron, copper, iron, manganese, molybdenum, and zinc were determined by dry ashing (Jones and Case, 1990) and inductively coupled plasma spectrophotometry (Jarrell-Ash ICAP 9000; Thermo Jarrell Ash Corp., Franklin, Mass.). All plant analysis was done at Micro-Macro Laboratories (Athens, Ga.). Data were analyzed by GLM and regressions using SAS Version 8 (SAS Institute, Inc., Cary, N.C.). 
Table 1. Analysis of variance of fertilizer rate on dry weight, leaf area, and overall plant quality for Strobilanthes dyerianus.

\begin{tabular}{lcrcc}
\hline Parameter & Source & df & Mean square & $P$ \\
\hline Shoot dry weight $(\mathrm{g})$ & Model & 9 & 432 & $<0.0001^{*}$ \\
& Error & 20 & 14.3 & \\
Leaf area $\left(\mathrm{cm}^{2}\right)$ & Model & 9 & 8828693 & $<0.0001^{*}$ \\
& Error & 20 & 139777 & \\
Quality & Model & 9 & 2.13 & $<0.0001^{*}$ \\
Error & 20 & 0 & & \\
\hline
\end{tabular}

2Plant quality ratings were determined on a scale of 0 to 4 , with $0=$ dead and $4=$ excellent.

"Significant at $P \leq 0.05$.

\section{Results and Discussion}

Plant quality and growth. The rate of fertilizer applied affected overall plant quality, shoot dry weight and leaf area of $S$. dyerianus (Table 1). However, there was little visible difference among plants receiving some amount of fertilizer, and all plants treated with 100 , 200,300 , or $400 \mathrm{mg} \cdot \mathrm{L}^{-1} \mathrm{~N}$ were given overall quality ratings of 4 (excellent) (data not presented). Fertilizer concentrations from 200 to $400 \mathrm{mg} \cdot \mathrm{L}^{-1}$ resulted in plants with the largest shoot dry weight and leaf area (Figs. 1 and 2). Despite similar quality, plants fertilized with $100 \mathrm{mg} \cdot \mathrm{L}^{-1} \mathrm{~N}$ had lower shoot dry weights and less leafarea than higher levels of $\mathrm{N}$. Regression indicates maximum dry weight at $300 \mathrm{mg} \cdot \mathrm{L}^{-1}$ $\mathrm{N}$, however the data points are very close to each other for the 200,300 , and $400 \mathrm{mg} \cdot \mathrm{L}^{-1}$ $\mathrm{N}$ treatments. Kuehny et al. (2000) noted no significant differences in shoot dry weight or quality of five poinsettia cultivars grown under different rates of fertilizer. Kovacic and Holcomb (1981) found Kalanchoe blossfeldiana v. Poelln 'Pixie' (kalanchoe) grown with 7-17.5-5 controlled-release fertilizer had no difference in quality when grown with 11.8 $\mathrm{kg} \cdot \mathrm{m}^{-3}$, two, or four times that rate. Whipker et al. (1999) recommended an $\mathrm{N}$ rate of 150 or 200 $\mathrm{mg} \cdot \mathrm{L}^{-1}$, depending on cultivar, for Impatiens walleriana Hook. (Double impatiens). Other fertilizer recommendations include $200 \mathrm{mg} \cdot \mathrm{L}^{-1}$ $\mathrm{N}$ for Petunia $\times$ hybrida Hort. ex. Vilm. 'Coral Sea,' for the greatest dry weight, branch length and flowering (Frett et al., 1985). Campos and Reed (1993) observed greatest leaf area with rates of 100 to $200 \mathrm{mg} \cdot \mathrm{L}^{-1} \mathrm{~N}$ for the tropical plant Spathiphyllum Schott. and 200 to 400 $\mathrm{mg} \cdot \mathrm{L}^{-1} \mathrm{~N}$ for the tropical plant Dieffenbachia Schott.

Electrical conductivity. The rate of fertilizer applied had a significant effect on substrate electrical conductivity (EC) over the course of the experiment as expected (Table 2). Plants receiving no fertilizer ( 0 rate) had the lowest EC levels and foliage was chlorotic and stunted, compared to the other treatments. A low EC is associated with a malnourished plant, which may be visually noted by stunted growth or leaf discoloration (varying depending on the deficient nutrient) (Whipker et al., 2001). On the contrary, a high EC may contribute to necrotic leaf margins, poor or erratic rooting of cuttings and increased vulnerability to dis- eases affecting the root and crown (Dole and Wilkins, 1999). Morvant et al. (1997) found that lower concentrations of soluble salts in the substrate encouraged root growth, while higher concentrations of substrate soluble salts inhibited root growth.

Strobilanthes dyerianus, though a tropical perennial, is usually grown as an annual in temperate climates. Using information on recommended EC levels for bedding plants, the treatments receiving 300 and $400 \mathrm{mg} \cdot \mathrm{L}^{-1} \mathrm{~N}$ had excessively high levels of soluble salts (Table 2). Similar salt accumulations at higher rates of N were seen by Campos and Reed (1993) for Spathiphyllum and Dieffenbachia which ultimately led to plant death. For S. dyerianus, the $200 \mathrm{mg} \cdot \mathrm{L}^{-1} \mathrm{~N}$ treatment maintained the EC within the recommended range for bedding plants of 1.0 to $2.6 \mathrm{mS} \cdot \mathrm{cm}^{-1}$ (Whipker et al., 2001) throughout the experiment. The fact that there was no difference in overall plant quality suggests that $S$. dyerianus is tolerant of excess substrate soluble salts. Similar performance was noted in Viola $\times$ wittrockiana Gam., which produced optimal leaf area and shoot dry weight at a leachate $\mathrm{EC}$ ranging from 1.5 to $4.0 \mathrm{dS} \cdot \mathrm{m}^{-1}$ (van Iersel, 1999).

$p H$. The substrate $\mathrm{pH}$ was also affected by the fertilizer treatment (Table 2). The recommended $\mathrm{pH}$ range for soilless substrate is between 5.4 and 6.0; however, this can vary depending on crop type (Dole and Wilkins, 1999). Only plants receiving $0 \mathrm{mg} \cdot \mathrm{L}^{-1} \mathrm{~N}$ had a substrate $\mathrm{pH}$ that fell within this range (Table 2). By termination of the experiment, $\mathrm{pH}$ for the $100,200,300$, and $400 \mathrm{mg} \cdot \mathrm{L}^{-1} \mathrm{~N}$ treatments had dropped as low as 3.4, decreasing with increasing $\mathrm{N}$ concentrations. Though a supposedly basic fertilizer was used $(15 \mathrm{~N}-2.2 \mathrm{P}-12.4 \mathrm{~K})$,

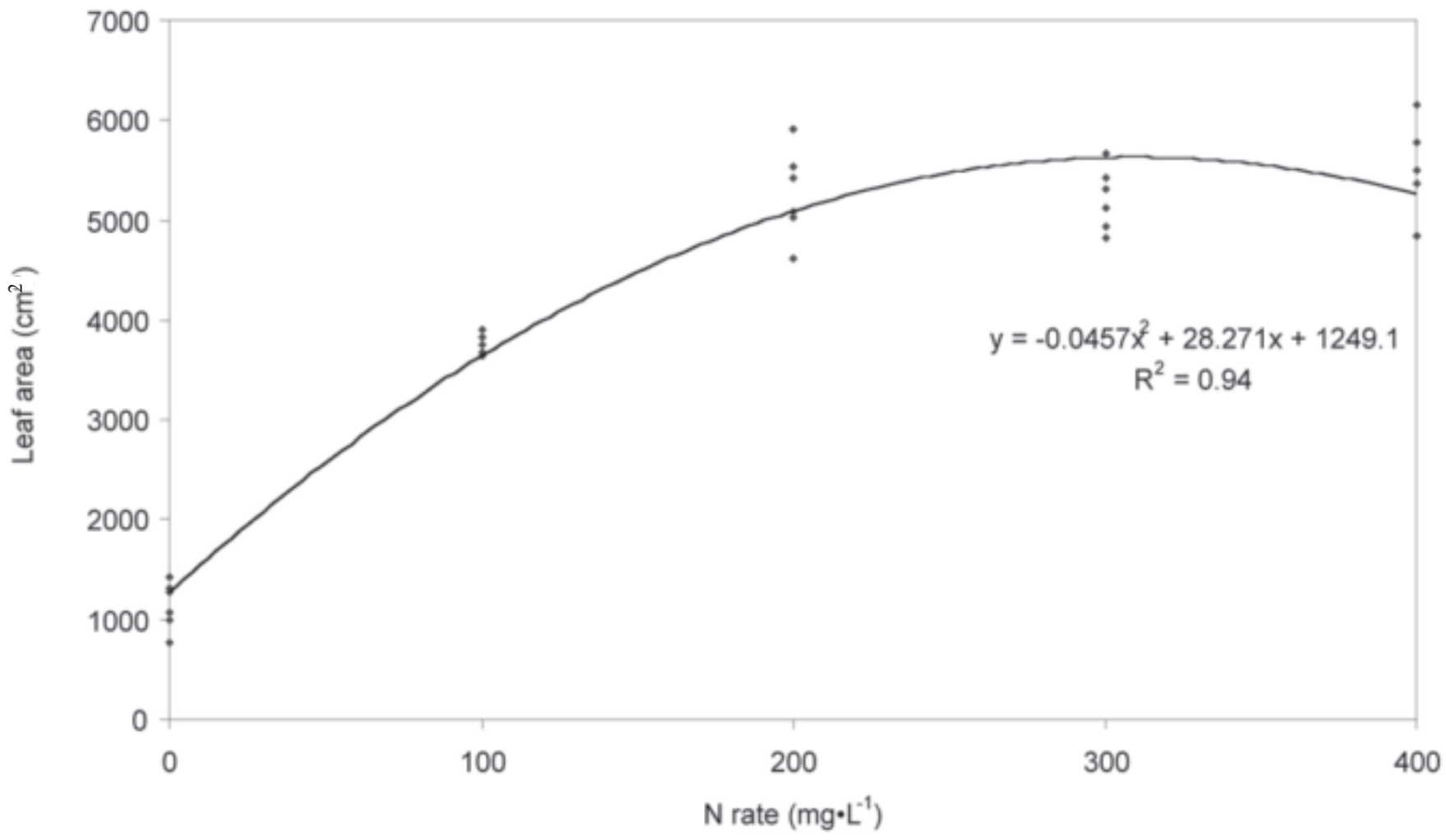

Fig. 1. Leaf area of Strobilanthes dyerianus measured 8 weeks after initiation of treatments, regressed over concentration of nitrogen in the fertilizer. 


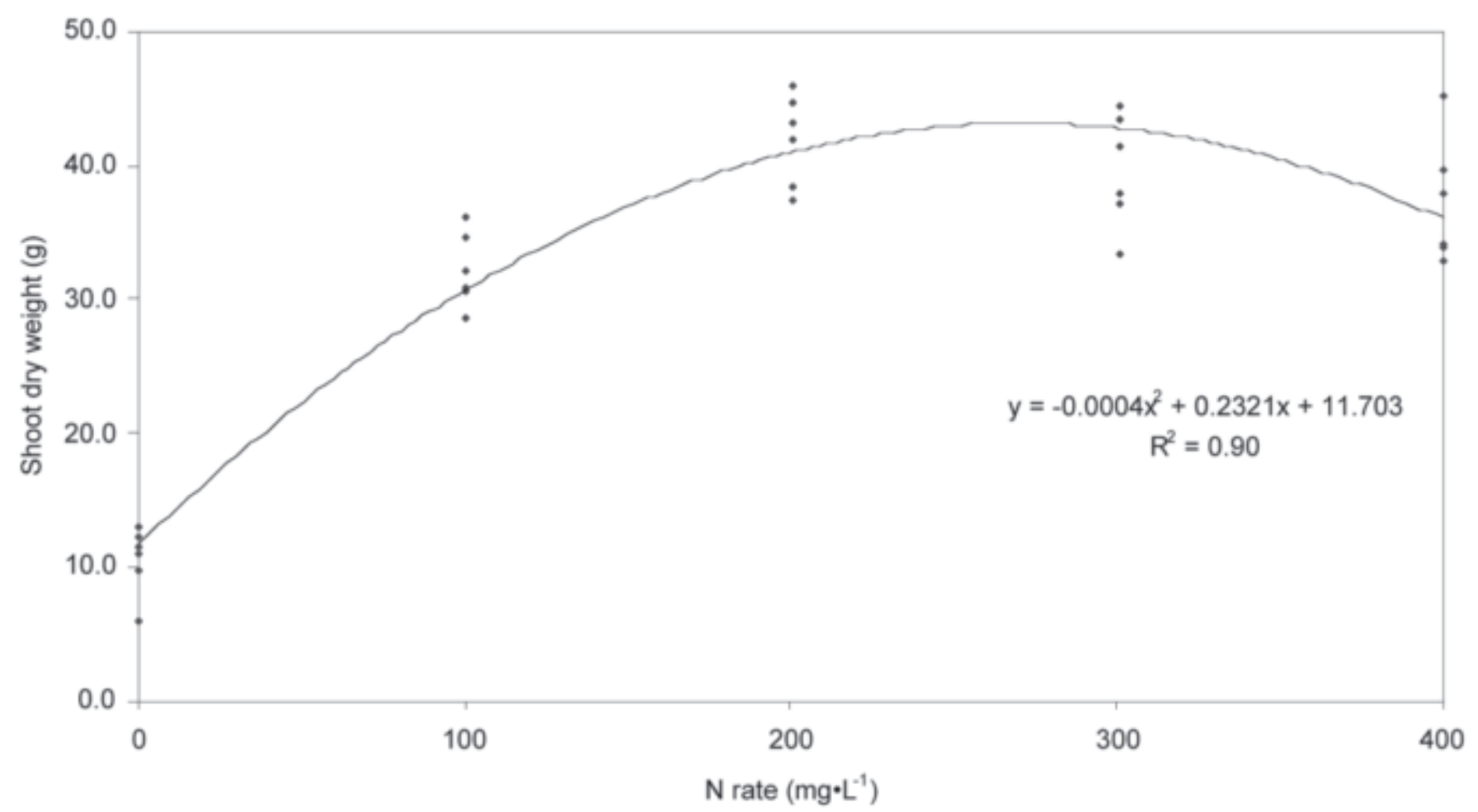

Fig. 2. Shoot dry weight of Strobilanthes dyerianus, measured 8 weeks after initiation of treatments, and regressed over concentration of nitrogen in the fertilizer.

Table 2. Mean substrate electrical conductivity (EC) and pH for Strobilanthes dyerianus. Measured weekly by the pour-through extraction method from the beginning of fertilizer treatments until termination (Week 5 data excluded due to equipment malfunction) $(n=6)$.

\begin{tabular}{lccccccc}
\hline & \multicolumn{7}{c}{ Week } \\
\cline { 2 - 8 } Rate $\left(\mathrm{mg} \cdot \mathrm{L}^{-1} \mathrm{~N}\right)$ & 1 & 2 & 3 & 4 & 6 & 7 & 8 \\
\hline EC $\left(\mathrm{dS} \cdot \mathrm{m}^{-1}\right)$ & 1.00 & 0.53 & 0.24 & 0.18 & 0.13 & 0.14 & 0.13 \\
$\quad 0$ & 1.67 & 1.08 & 0.88 & 0.63 & 0.48 & 0.44 & 0.68 \\
100 & 2.19 & 1.94 & 2.02 & 1.81 & 2.34 & 3.01 & 2.79 \\
200 & 3.04 & 3.02 & 3.39 & 3.34 & 3.94 & 4.10 & 4.37 \\
300 & 3.69 & 3.97 & 4.68 & 4.42 & 5.16 & 4.93 & 5.38 \\
400 & & & & & & & \\
$\mathrm{pH}$ & 6.1 & 5.9 & 6.0 & 5.9 & 5.6 & 5.5 & 4.9 \\
0 & 6.0 & 5.9 & 5.7 & 5.6 & 5.1 & 4.9 & 4.2 \\
100 & 5.8 & 5.6 & 5.3 & 5.1 & 4.2 & 4.0 & 3.4 \\
200 & 5.7 & 5.6 & 5.2 & 5.0 & 4.1 & 4.1 & 3.4 \\
300 & 5.7 & 5.5 & 5.3 & 5.1 & 4.2 & 4.3 & 3.6 \\
400 & & & & & & & \\
\hline
\end{tabular}

we saw a decrease in $\mathrm{pH}$, both over time and with increasing rates. van Iersel (2003) reported decreases in substrate $\mathrm{pH}$ associated with increasing fertilizer concentrations and attributed this decrease to the actual $\mathrm{pH}$ of the fertilizer solution. Substrate $\mathrm{pH}$ can be affected by the breakdown of the components in the substrate, irrigation water alkalinity, and the acidity-basicity of the fertilizer being used. A pH that is too far outside of the optimal range can cause problems with nutrient availability, rendering certain nutrients, particularly micronutrients, unavailable for uptake by the plant (Whipker et al., 2001). However, the plants did not show any visible nutrient deficiency or toxicity symptoms, and the tissue elemental content was in agreement with two similar species from the Acanthaceae family (Table 3).

Tissue elemental content. Most foliar elements increased linearly with increasing fertilizer rates (Table 3). Exceptions were S, Fe, and Mo, which exhibited quadratic increases, and $\mathrm{Mn}, \mathrm{Ca}$, and $\mathrm{Mg}$, which exhibited a quadratic decrease. There was a sharp decrease (or increase, depending on the nutrient) in the tissue elemental concentrations of these six elements when the fertilizer concentration increased from 0 to $100 \mathrm{ppm}$, then little effect on nutrient concentrations with a further increase in fertilizer concentration. The decrease in $\mathrm{Ca}$ and $\mathrm{Mg}$ can most likely be attributed to the dilution effect, that is, more dry matter at higher fertilizer concentrations. While $\mathrm{Ca}$ and $\mathrm{Mg}$ are often present in higher concentrations than $\mathrm{K}$ in soils, $\mathrm{K}$ is taken up quickly and at higher rates (Mengel and Kirkby, 2001). Calcium can only be taken up by young root tips, while the uptake mechanism of $\mathrm{Mg}$ is not fully understood (Mengel and Kirkby, 2001). Similar decreases in Ca due to increased K have been noted in double impatiens (Whipker et al., 1999) and in poinsettia (Whipker and Hammer, 1997).
The elemental concentration averages of three samples per treatment are reported in Table 3. The tissue elemental content of $S$. dyerianus was comparable to the sufficiency data from two other species in the Acanthaceae family, Aphelandra squarrosa Nees. (zebra plant) and Fittonia verschaffeltii var. argyroneura Coem. (silver nerve plant) as presented in Mills and Jones (1996).

In conclusion, there was no visible difference in the quality of plants produced with $100,200,300$, or $400 \mathrm{mg} \cdot \mathrm{L}^{-1} \mathrm{~N}$, and the largest plants (quantified by shoot dry weight and leaf area) were produced by 200 and 300 $\mathrm{mg} \cdot \mathrm{L}^{-1} \mathrm{~N}$. However, EC values indicated relatively high soluble salts in the substrate at 300 $\mathrm{mg} \cdot \mathrm{L}^{-1} \mathrm{~N}$. Only the $200 \mathrm{mg} \cdot \mathrm{L}^{-1} \mathrm{~N}$ treatment maintained a substrate EC level within the range recommended for the production of most bedding plants (1.0 to $\left.2.6 \mathrm{dS} \cdot \mathrm{m}^{-1}\right)$.

Though substrate $\mathrm{pH}$ was low towards the end of the study, tissue analysis results suggest that the $\mathrm{pH}$ differences had little effect on growth as there was no indication of micronutient toxicity. That in turn suggests that growth effects were probably due to substrate EC. With mounting environmental concerns such as $\mathrm{N}$ (nitrate) and $\mathrm{P}$ runoff along with potential total maximum daily load (TMDL) restrictions imposed by local or state governments, growers should take every opportunity to reduce fertilizer inputs, especially if they can be reduced without compromising quality. A nutrition regime consisting of $200 \mathrm{mg} \cdot \mathrm{L}^{-1} \mathrm{~N}$ from a complete fertilizer is appropriate for producing high quality $S$. dyerianus plants. Elemental tissue concentration from these foliar analyses may be helpful in evaluations of nutrient sufficiency. 
Table 3. Foliar elemental content of Strobilanthes dyerianus harvested 8 weeks after treatment with five fertilizer rates $(n=3)$. Also interpretive values for two other herbaceous Acanthaceae taxa.

\begin{tabular}{|c|c|c|c|c|c|c|c|c|c|c|c|c|}
\hline \multirow{2}{*}{$\begin{array}{l}\text { Rate } \\
\left(\mathrm{mg} \cdot \mathrm{L}^{-1} \mathrm{~N}\right)\end{array}$} & \multicolumn{6}{|c|}{ Elemental content $\left(\mathrm{g} \cdot \mathrm{kg}^{-1}\right)$} & \multicolumn{6}{|c|}{ Element content $\left(\mu \mathrm{g} \cdot \mathrm{g}^{-1}\right)$} \\
\hline & $\mathrm{N}$ & $\mathrm{P}$ & $\mathrm{K}$ & $\mathrm{Ca}$ & $\mathrm{Mg}$ & $\mathrm{S}$ & $\mathrm{Fe}$ & $\mathrm{Mn}$ & $\mathrm{B}$ & $\mathrm{Cu}$ & $\mathrm{Zn}$ & Mo \\
\hline 100 & 31.0 & 4.73 & 29.3 & 15.1 & 10.8 & 1.70 & 61.4 & 127.0 & 42.4 & 3.79 & 36.0 & 5.19 \\
\hline 400 & 46.5 & 6.12 & 52.2 & 12.7 & 8.9 & 1.67 & 66.8 & 133.0 & 103.0 & 6.46 & 53.9 & 3.42 \\
\hline Significance $^{z}$ & $\mathrm{~L}$ & $\mathrm{~L}$ & $\mathrm{~L}$ & L & $\mathrm{L}$ & $\mathrm{Q}$ & Q & Q & L & $\mathrm{L}$ & $\mathrm{L}$ & $\mathrm{Q}$ \\
\hline Fittonia $^{\mathrm{y}}$ & 41.6 & 7.6 & 56.9 & 22.4 & 13.4 & 6.3 & 114.0 & 80.0 & 41.0 & 9.00 & 61.0 & 3.0 \\
\hline
\end{tabular}

${ }^{2}$ Significant linear (L) or quadratic (Q) effects at $P \leq 0.05$.

`Interpretive values: survey average for Fittonia verschaffeltii var. argyroneura and sufficiency range for Aphelandra squarrosa. From Mills and Jones, 1996.

\section{Literature Cited}

Armitage, A.M. and M. Green. 2001. The university trial garden as a tool for evaluating and introducing new plant materials. HortTechnology 11:368-372.

Campos, R. and D.W. Reed. 1993. Determination of constant-feed liquid fertilization rates for Spathiphyllum 'Petite' and Dieffenbachia 'Camille'. J. Environ. Hort. 11:22-24.

Dole, J.M. and H.T. Wilkins. 1999. Floriculture principles and species. Prentice Hall, Upper Saddle River, N.J.

Foth, H.D. and B.G. Ellis. 1997. Soil fertility. CRC Press, Boca Raton, Fla.

Frett, J.J., M.A. Dirr, and A.M. Armitage. 1985. Nitrogen and calcium requirements of Petunia $\times$ hybrida 'Coral Sea'. Sci. Hort. 26:351-359.

James, E.C. and M.W. van Iersel. 2001. Fertilizer concentration affects growth and flowering of subirrigated petunias and begonias. HortScience 36:40-44.
Jones, J.B. 1998. Plant nutrition manual. CRC Press, Boca Raton, Fla.

Jones, J.B. and V.W. Case. 1990. Sampling, handling, and analyzing plant tissue samples, p. 389-427. In: R.L. Westerman (ed.). Soil testing and plant analysis. Soil Sci. Soc. Amer., Madison, Wis.

Kovacic, M.T. and E.J. Holcomb. 1981. Effects of controlled-release fertilizers and application methods on growth and leaf elemental concentration of Kalanchoe blossfeldiana 'Pixie'. J. Amer. Soc. Hort. Sci. 106:549-552.

Kuehny, J.S., P.C. Branch, and P.W. Adams. 2000. Effect of constant versus adjusted commercial fertilizer concentrations on poinsettia. J. Plant Nutr. 23:551-568.

Mengel, K. and E.A. Kirkby. 2001. Principles of plant nutrition. 5th ed. Kluwer Academic, The Netherlands.

Mills, H.A. and J.B. Jones. 1996. Plant analysis handbook II. MicroMacro Publ., Athens, Ga.

Morvant, J.K., J.M. Dole, andE.Allen. 1997. Irrigation systems alter distribution of roots, soluble salts, nitrogen and $\mathrm{pH}$ in the root medium. HortTechnology 7:156-160.

van Iersel, M. 1999. Fertilizer concentration affects growth and nutrient composition of subirrigated pansies. HortScience 34:660-663.

van Iersel, M. 2003. Actual $\mathrm{pH}$ and potential acidity of fertilizer solutions determine the $\mathrm{pH}$ of soilless mixes. Proceedings of the SNA research conference. 48th Annu. Rpt. p. 538-541.

Whipker, B.E. and P.A. Hammer. 1997. Nutrient uptake in poinsettia during different stages of physiological development. J. Amer. Soc. Hort. Sci. 122:565-573.

Whipker, B.E., J.M. Dole, T.J. Cavins, J.L. Gibson, W.C. Fonteno, P.V.Nelson, D.S Pitchay, and D.A. Bailey. 2001. Plant root zone management. N.C. Comm. Flower Growers' Assn., Raleigh, N.C.

Whipker, B.E., S. Dasoju, M.S. Dosmann, and J.K. Iles. 1999. Effect of fertilizer concentration on growth of double impatiens. HortTechnology 9:425-428.

Wright, R.D. 1986. The pour-through nutrient extraction procedure. HortScience 21:227-229. 